The suspension rate due to toxicity decreased $(p<0.05)$, while the clinical remission rate improved $(p<0.01)$.

Abstract AB0223 - Table 1

\begin{tabular}{|c|c|c|c|c|c|c|}
\hline & Global & $\begin{array}{c}1980- \\
1990\end{array}$ & $\begin{array}{c}1991- \\
2000\end{array}$ & $\begin{array}{c}2001- \\
2010\end{array}$ & $\begin{array}{c}2011- \\
2015\end{array}$ & $\begin{array}{c}\text { Valour } \\
\mathbf{p}\end{array}$ \\
\hline $\begin{array}{l}\text { Diagnosis age (years), mean } \\
\text { (SD) }\end{array}$ & $\begin{array}{c}49,6 \\
(13,2)\end{array}$ & $\begin{array}{c}39,4 \\
(11,6)\end{array}$ & $\begin{array}{c}44,0 \\
(11,0)\end{array}$ & $\begin{array}{c}52,6 \\
(13,5)\end{array}$ & $\begin{array}{c}51,6 \\
(11,9)\end{array}$ & $<0,01$ \\
\hline $\begin{array}{l}\text { Diagnostic delay (months) mean } \\
\text { (SD) }\end{array}$ & $\begin{array}{c}17,2 \\
(27,1)\end{array}$ & $\begin{array}{l}21,7 \\
(29,8)\end{array}$ & $\begin{array}{c}21,0 \\
(34,6)\end{array}$ & $\begin{array}{l}15,7 \\
(26,0)\end{array}$ & $\begin{array}{c}15,3 \\
(19,2)\end{array}$ & NS \\
\hline $\begin{array}{l}\text { Diagnostic-treatment interval } \\
\text { (months), mean (SD) }\end{array}$ & $\begin{array}{l}24,0 \\
(38,9)\end{array}$ & $\begin{array}{c}34,5 \\
(66,8)\end{array}$ & $\begin{array}{c}11,7 \\
(25,2)\end{array}$ & $\begin{array}{c}2,7 \\
(7,7)\end{array}$ & $\begin{array}{c}1,4 \\
(3,2)\end{array}$ & $<0,01$ \\
\hline Extra-articular invovement, $n(\%)$ & $71\left(^{23,6}\right.$ & $12^{52,2}$ & $25\left(^{39,1}\right.$ & $27\left({ }^{18,2}\right.$ & $\begin{array}{c}7 \\
(10,6)\end{array}$ & $<0,01$ \\
\hline $\begin{array}{l}\text { Baseline DAS28-RCP, mean } \\
\text { (SD) }\end{array}$ & $\begin{array}{c}4,5 \\
(0,8)\end{array}$ & $\begin{array}{c}5,2 \\
(0,8)\end{array}$ & $\begin{array}{c}4,6 \\
(0,8)\end{array}$ & $\begin{array}{c}4,3 \\
(0,8)\end{array}$ & $\begin{array}{c}4,3 \\
(0,8)\end{array}$ & $<0,01$ \\
\hline Baseline $\mathbf{R C P}(\mathrm{mg} / \mathrm{l})$, mean $(\mathrm{SD})$ & $\begin{array}{c}17,8 \\
(21,3)\end{array}$ & $\begin{array}{c}27,8 \\
(28,9)\end{array}$ & $\begin{array}{c}18,4 \\
(17,8)\end{array}$ & $\begin{array}{c}18,9 \\
(23,3)\end{array}$ & $\begin{array}{c}10,9 \\
(13,7)\end{array}$ & $<0,01$ \\
\hline Erosions, $\mathrm{n}(\%)$ & $\begin{array}{l}163 \\
(55,6\end{array}$ & $20\left(^{90,9}\right.$ & $48\left(^{77,4}\right.$ & $77\left({ }^{53,8}\right.$ & $18\left(^{27,3}\right.$ & $<0,01$ \\
\hline MTX weekly (mg), mean (SD) & $\begin{array}{l}16,5 \\
(3,7)\end{array}$ & $\begin{array}{l}16,5 \\
(4,2)\end{array}$ & $\begin{array}{l}16,6 \\
(3,6)\end{array}$ & $\begin{array}{l}16,5 \\
(3,7)\end{array}$ & $\begin{array}{l}16,2 \\
(3,6)\end{array}$ & NS \\
\hline MTX SC way, $n(\%)$ & $\begin{array}{l}177 \\
(58,8\end{array}$ & $12^{52,2}$ & $37\left({ }^{57,8}\right.$ & $87\left({ }^{58,8}\right.$ & $41\left(^{62,1}\right.$ & NS \\
\hline Withdrawn by $\mathrm{AE}, \mathrm{n}(\%)$ & $52\left({ }^{17,3}\right.$ & $\begin{array}{c}6 \\
(27,3)\end{array}$ & $18\left(^{27,7}\right.$ & $20\left({ }^{13,5}\right.$ & $\begin{array}{c}8 \\
(12,1)\end{array}$ & $<0,05$ \\
\hline Remission, $n(\%)$ & $\begin{array}{r}100 \\
\left({ }^{33,2}\right. \\
\end{array}$ & $2(8,7)$ & $14\left(^{21,9}\right.$ & $56\left(^{37,8}\right.$ & $28\left(^{42,4}\right.$ & $<0,01$ \\
\hline
\end{tabular}

Conclusions: In our cohort, the severity of RA has decreased during the last four decades, the time to start MTX has been reduced and better remission rates with MTX monotherapy have been achieved.

REFERENCE:

[1] Silman AJ. Trends in the incidence and severity of rheumatoid arthritis. J Rheumatol 1992;19(suppl 32):71-3.

Disclosure of Interest: None declared DOI: 10.1136/annrheumdis-2018-eular.3961

\section{AB0224 CERVICAL PROPRIOCEPTIVE IMPAIREMENT IN PATIENTS WITH RHEUMATOID ARTHRITIS}

F. Ulutatar ${ }^{1}$, M.T. Duruoz ${ }^{2} .{ }^{1} P M R$ Department, ${ }^{2} P M R$ Department, Rheumatology Division, Marmara University School of Medicine, Istanbul, Turkey

Background: Rheumatoid arthritis (RA) is autoimmune disease that usually involves cervical part of the vertebral column which can cause cervical proprioceptive deficit.

Objectives: Assessment of cervical proprioception and its relation with radiographic, clinical and functional characteristics of patients with RA

Methods: Rheumatoid arthritis patients who diagnosed according to ACR $2010 \mathrm{cri}-$ teria and control group with healthy volunteers were recruited in the study. Demographic and clinical parameters were noted. Cervical proprioception was evaluated by Cervical Joint Position Error Test (CJPET). Functional assessment scales that used in this study were Multidimensional Assessment of Fatigue (MAF), Beck Depression Inventory, Health Assessment Questionairre (HAQ), Euroqol 5D (EQ-5D) and Berg Balance Scale. Cervical subluxations were noted according to cervical radiographic image. The differerence in mean scores of CJPET between RA patients and healthy volunteers were analysed with MannWhitney U test. Spearman correlation coefficient (rho) was used for correlations between functional parameters. Regression analysis was used for grading factors which had relations with cervical proprioception.

Results: One hundred six rheumatoid arthritis patients and one hundred six healthy volunteers were enrolled in this study. Mean age of patients and healthy volunteers were 51,0 (Sd:11,1) and 48,9 (Sd:9,2), respectively. Scores of CJPET are statistically significantly higher in rheumatoid arthritis group than healthy volunteers $(p=0,001)$ (table 1$)$. CJPET scores are negatively correlated with Berg Balance Scale results in all directions ( $r h o=-0,421,-0,473,-0,448,-0,515$ ). Scores of CJPET in patients with atlantoaxial subluxations (AAS) were statistically significantly higher than those without AAS $(p=0,002-0,045)$. Regression analysis results showed that $A A S$ is related with worser cervical proprioception on right and left rotations. There were no correlation between CJPET scores and functional parameters. Weak corelation were found in scores of CJPET with age and educational status.
Abstract AB0224 - Table 1. Comparison of cervical joint position error test scores between rheumatoid arthritis patients and healthy volunteers

\begin{tabular}{|c|c|c|c|c|}
\hline & \multicolumn{2}{|r|}{ Patients } & \multirow{2}{*}{$\frac{\text { Healthy Volunteers }}{\text { Mean } \pm S D}$} & \multirow[t]{2}{*}{$\mathbf{P}$} \\
\hline & Min-Max & Mean \pm SD & & \\
\hline CJPET- Right Rotation $^{1-6}$ & $1,66-6,00$ & $4,55 \pm 1,30$ & $3,03 \pm 0,81$ & 0001 \\
\hline CJPET- Left Rotation ${ }^{1-6}$ & $1,50-6,00$ & $4,52 \pm 1,37$ & $3,07 \pm 0,95$ & 0001 \\
\hline CJPET- Flexion ${ }^{1-6}$ & $1,00-6,00$ & $4,52 \pm 1,36$ & $2,98 \pm 0,89$ & 0001 \\
\hline CJPET- Extension ${ }^{1-6}$ & $1,50-6,00$ & $4,57 \pm 1,29$ & $3,00 \pm 0,93$ & 0001 \\
\hline \multicolumn{5}{|c|}{$\begin{array}{l}\text { CJPET: Cervical Joint Position Error Test, SD: Standard } \\
\text { Deviation, } p<0,05 \text { is significant }\end{array}$} \\
\hline
\end{tabular}

Conclusions: Cervical proprioception is impaired in rheumatoid arthritis patients. This impairement is increased with the existance of atlantoaxial subluxations and balance problems.

Disclosure of Interest: None declared

DOI: 10.1136/annrheumdis-2018-eular.6903

\section{AB0225 CLINICAL OUTCOMES OF TREATMENT WITH GOLIMUMAB IN SEROPOSITIVE AND SERONEGATIVE RHEUMATOID ARTHRITIS PATIENTS IN REAL-LIFE SETTINGS. DATA FROM ITALIAN REGISTER GISEA}

F. lannone $^{1}$, R. Caporali ${ }^{2}$, V. Grosso ${ }^{2}$, E.G. Favalli ${ }^{3}$, A. Marchesoni ${ }^{3}$, S. D'Angelo ${ }^{4}$, G. Tramontano ${ }^{4}$, P. Sarzi-Puttini ${ }^{5}$, F. Atzeni ${ }^{5}$, F. Conti ${ }^{6}$, F. Miranda ${ }^{7}$, R. Foti $^{8}$, G. Amato ${ }^{8}$, A. Carletto ${ }^{9}$, I. dal Forno ${ }^{9}$, E. Gremese ${ }^{10}$, A.L. Fedele ${ }^{10}$, A. Cauli ${ }^{11}$, D. Perra ${ }^{11}$, R. Ramonda ${ }^{12}$, M. Lorenzin ${ }^{12}$, M. Sebastiani ${ }^{13}$, G. Cassone ${ }^{13}$ O. Epis ${ }^{14}$, C. Casu ${ }^{14}$, E. Fusaro ${ }^{15}$, M. Priora ${ }^{15}$, M. Govoni ${ }^{16}$, F. Bergossi ${ }^{16}$, F. P. Cantatore ${ }^{17}$, F. D'Onofrio ${ }^{17}$, L. Cantarini ${ }^{18}$, S. Gentileschi ${ }^{18}$, F. Salaffi ${ }^{19}$, M. Di Carlo ${ }^{19}$, G. Lapadula ${ }^{1} .{ }^{1}$ DETO-Rheumatology Unit, BARl; ${ }^{2}$ Reumatologia, Università e Fondazione Policlinico S. Matteo, Pavia; ${ }^{3}$ Department of Rheumatology, Gaetano Pini Institute, Milano; ${ }^{4}$ Rheumatology Department of Lucania, San Carlo Hospital, Potenza: ${ }^{5}$ Rheumatology, Hospital Sacco, Milano; ${ }^{6}$ Reumatologia; ${ }^{7}$ Rheumatology, Sapienza Università di Roma, Roma; ${ }^{8} \mathrm{UO}$ Reumatologia, A.O.U. Policlinico V.E., Catania; ${ }^{9}$ Reumatologia, AOUI Verona, Verona; ${ }^{10}$ UOC of Rheumatology, Fondazione Policlinico A. Gemelli-UCSC, Roma; ${ }^{11}$ SC di Reumatologia, AOU e Università di Cagliari, Cagliari, ${ }^{12}$ Rheumatology Unit, DIMED, University of Padova, Padova; ${ }^{13}$ UOC Reumatologia, Università degli Studi di Modena, Modena; ${ }^{14}$ Reumatologia, Ospedale Niguarda., Milano; ${ }^{15} \mathrm{SC}$ di Reumatologia, AOU Città della Salute e della Scienza di Torino, Torino;

${ }^{16}$ Rheumatology, Department of Medical Sciences, University of Ferrara, Ferrara; ${ }^{17}$ Clinica Reumatologica, Università di Foggia, Foggia; ${ }^{18}$ Rheumatology, Università di Siena, Siena; ${ }^{19}$ Rheumatology, Polytechnic University of Marche, Jesi, Italy

Background: There is evidence that autoimmunity, namely RF and ACPA antibodies, may influence disease activities and impact the clinical outcomes in RA.

Objectives: There is evidence that autoimmunity, namely RF and ACPA antibodies, may influence disease activities and impact the clinical outcomes in RA.

Methods: We analysed longitudinal data of consecutive RA patients from the Italian registry GISEA, starting a treatment with golimumab (GOL) and tested for rheumatoid factor (RF) and anti-citrullinated protein antibodies (ACPA). Demographic and disease related characteristics were collected at baseline, 6 months, 12, and 24 months or at last observation visit. Primary endpoint was the persistence on GOL in RF/ACPA +ve and RF/ACPA patients. Secondary endpoint was the search of baseline predictors of drug survival and clinical outcomes $n$ the two RA subsets. Drug survival was evaluated by Kaplan-Meier life table analysis. Estimates hazard ratios (HRs, 95\% confidence intervals $(\mathrm{Cl})$ ) of drug discontinuation or achievement of low-disease adjusted for patient's demographics, disease characteristics and prior biologic treatments were computed by Cox-regression stepwise backward models.

Results: 345 patients had data on RA and ACP testing and were included in this analysis. No significant difference in terms of age, BMI, disease activity, co-therapy with glucocorticoids or methotrexate (MTX) was detected between RF/ACPA+ve and RF/ACPA-ve patients, but the former had significantly higher disease duration (10.6 $\pm \mathrm{vs} 8.2 \pm 6$ years) and frequencies of comorbidities $(60.6 \%$ vs $44.2 \%)$. The 2 years global drug retention was $64.5 \%$, and it was almost identical in RF/ACPA+ve $64.2 \%$ and in RF/ACPA-ve 65\% RA patients. Drug survival was not influenced by the gender or cause of discontinuation (adverse or inefficacy). To note, in $31 \%$ of the patients GOL was not associated to MTX.

The only predictor of drug discontinuation was the lack of MTX at baseline (HR $1.62,95 \mathrm{Cl} 1.07-2.46, \mathrm{p}=0.02$ ), and the GOL-naïve status (HR 0.62, $95 \mathrm{Cl} 0.39$ $0.99, \mathrm{p}=0.04)$. At two years, $44.4 \%$ achieved the state of low-disease activity (DAS28 <3.2) with no difference between RF/ACPA+ve $(45.4 \%)$ and RF/ACPAve $(42.0 \%)$ patients, and none baseline factor correlating with low disease activity. No safety issues were raised during the study. 
Conclusions: In this study, we demonstrated that RF/ACPA positivity does not negatively impact on drug survival on golimumab. This may aid rheumatologists in their clinical decisions.

Disclosure of Interest: None declared

DOI: 10.1136/annrheumdis-2018-eular.6174

\section{AB0226 DECLINE IN ANTI-CCP AND RHEUMATOID FACTOR LEVELS IN PATIENTS WITH EARLY RHEUMATOID ARTHRITIS AFTER 2 YEARS OF TREATMENT WITH INTENSIVE COMBINATION STRATEGIES, INCLUDING PREDNISOLONE: THE COBRA-LIGHT TRIAL}

H.D. Folmo ${ }^{1}$, M.M. ter Wee ${ }^{1,2}$, D. den Uyl ${ }^{1}$, N.P. Konijn ${ }^{1}$, P.J. Kerstens ${ }^{3,4}$, A. E. Voskuyl ${ }^{1}$, D. van Schaardenburg ${ }^{3,5}$, M.T. Nurmohamed ${ }^{1,3}$, M. Boers $^{1,2}$, W F. Lems ${ }^{1,3}$. ${ }^{1}$ Department of Rheumatology, Amsterdam Rheumatology and Immunology Center, ${ }^{2}$ Department of Epidemiology and Biostatistics, VU University Medical Center, ${ }^{3}$ Department of Rheumatology, Amsterdam Rheumatology and Immunology Center, Reade, Amsterdam; ${ }^{4}$ Department of Rheumatology, Westfriesgasthuis, Hoorn; ${ }^{5}$ Department of Rheumatology, Amsterdam Rheumatology and Immunology Center, Academic Medical Center, Amsterdam, Netherlands

Background: Previous studies have proven that the COBRA-light strategy has similar effectiveness and safety as the COBRA strategy in treating early rheumatoid arthritis (RA) patients ${ }^{1,2}$. However, the effect of these strategies on anti-cyclic citrullinated peptide (anti-CCP) and rheumatoid factor (RF) levels remains contradictory.

Objectives: To investigate whether levels of anti-CCP and RF have changed after 2 years of treatment with COBRA or COBRA-light strategy.

Methods: A total of 162 early RA patients were included in a randomised, openlabel, multicenter trial and treated with either COBRA or COBRA-light strategy. After 1 year, the treatment protocol ended, and physicians continued treatment according to clinical judgment, aiming at clinical remission. Log-transformation was first performed before running any analyses in case of skewed distribution, and analyses were performed with Generalised Estimated Equations to evaluate the association between the medication strategies and the change of LN antiCCP and LN RF levels on average over time.

Results: Over 2 years' time, median anti-CCP and RF levels decreased significantly in COBRA $(6 \%$, and $24 \%$ respectively) and COBRA-light $(4 \%$, and $13 \%$, respectively; table 1). Of the 102 anti-CCP positive patients at baseline, $10(10 \%)$ became anti-CPP negative during treatment (5 COBRA vs. 5 COBRA-light). No significant difference between the two treatment strategies on the change of antiCCP and RF levels over 2 years' time was found. Additionally, a significant association between baseline DAS44 and remaining anti-CCP positive over time was found $(\mathrm{OR}=1.8 ; 95 \% \mathrm{Cl}: 1.2-2.8)$

Abstract AB0226 - Table 1. Change in anti-CCP and IgM-RF levels over time

\begin{tabular}{|c|c|c|c|c|c|c|c|}
\hline & Baseline & Week 52 & $\begin{array}{c}\text { Absolute } \\
\text { median change }\end{array}$ & $\begin{array}{c}\text { Percentage } \\
\text { median } \\
\text { change }\end{array}$ & Week 104 & $\begin{array}{c}\text { Absolute } \\
\text { median change }\end{array}$ & $\begin{array}{c}\text { Percentage } \\
\text { median } \\
\text { change }\end{array}$ \\
\hline \multicolumn{8}{|l|}{ COBRA } \\
\hline Ant-CCP & $143(8-1182)$ & $81(7-710)$ & $-20(-427-0)$ & -14 & $109(7-507)$ & $-8(-314.0)$ & .6 \\
\hline $\begin{array}{l}\text { IgM-RF } \\
\text { COBRA- } \\
\text { lobt }\end{array}$ & $37(9-102)$ & $9(6-40)$ & $-9(-41-0)$ & -24 & $8(5-46)$ & $-9(-36-0)$ & -24 \\
\hline Ant-CCP & 229 (10.-961) & $80(7-499)$ & $-13(-249-0)$ & -6 & $32(7-402)$ & $-9(-235-0)$ & -4 \\
\hline IgM-RF & $40(10-132)$ & $12(6.50)$ & $-15(-79 .-0)$ & .38 & $13(6-84)$ & $-5(-48-1)$ & -13 \\
\hline
\end{tabular}

citrullinated peptide; IgM-RF, rheumatoid factor type IgM

Conclusions: Both COBRA and COBRA-light strategies lead to substantial decreases in anti-CCP and RF levels over 2 years of treatment. Patients with a higher DAS44 at baseline have higher odds of being anti-CCP positive over 2 years' time.

\section{REFERENCES:}

[1] ter Wee MM. Ann Rheum Dis. 2015;74(6):1233-1240. doi:10.1136/annrheumdis-2013-205143

[2] den Uyl D. Ann Rheum Dis. 2014;73(6):1071-1078. doi:10.1136/annrheumdis-2012-202818

Disclosure of Interest: None declared DOI: 10.1136/annrheumdis-2018-eular.5167

\section{AB0227 \\ TRANSCRIPTIONAL PROFILING OF SYNOVIAL MACROPHAGES USING MINIMALLY INVASIVE ULTRASOUND-GUIDED SYNOVIAL BIOPSIES IN RHEUMATOID ARTHRITIS}

H. Perlman, on behalf of RhEumatoid Arthritis SynOvial Tissue Network (REASON). Medicine/Rheumatology, Northwestern University, Chicago, USA

Background: Despite the many therapies for patients with rheumatoid arthritis (RA), there is little information to guide selection of the most effective treatment for an individual patient. Forty-sixty percent of patients with RA respond (defined by ACR50 response criteria) to conventional disease modifying anti-rheumatic drugs (cDMARDs) or cDMARDs plus anti-tumour necrosis factor (TNF) therapy. Moreover, $20 \%-40 \%$ of subjects in clinical trials never demonstrate even a minima response (ACR20 response criteria). Based on a population of over 300 million in the United States, a disease prevalence of $0.6 \%$, and a course of 3-4 months per biologic DMARD therapy, as much as $\$ 2.5$ billion is wasted annually on inadequate therapy. There is a clear need to develop precision-based therapy for patients with RA, whereby clinical information such as novel biomarkers will enhance our ability to predict the therapeutic response and thereby limit ineffec tive therapy.

Objectives: Currently, there are no reliable biomarkers for predicting therapeutic response in patients with rheumatoid arthritis (RA). The synovium may unlock critical information for determining efficacy as reduction in numbers of sublining synovial macrophages remains the most reproducible biomarker. Thus, a clinically actionable method for collection of synovial tissue, which can be analysed using high-throughput strategies, must become a reality.

Methods: Rheumatologists at six United States academic sites were trained in minimally invasive ultrasound-guided synovial tissue biopsy. Histology, fluorescence-activated cell sorting and RNA-seq were performed on biopsy synovial tissue from patients with RA and compared with osteoarthritis (OA) samples. An optimised protocol for digesting synovial tissue was developed to generate high quality RNA-seq libraries from isolated macrophage populations. Associations were determined between macrophage transcriptional profiles and clinical parameters of RA patients.

Results: Patients with RA reported minimal adverse effects in response to synovial biopsy. Comparable RNA quality was observed between synovial tissue and isolated macrophages from patients with RA and OA. Whole tissue samples from patients with RA demonstrated a high degree of transcriptional heterogeneity. In contrast, the transcriptional profile of isolated RA synovial macrophages high lighted a subpopulation of patients and identified six novel transcriptional modules that were associated with disease activity and therapy.

Conclusions: Performance of synovial tissue biopsies by rheumatologists in the United States is feasible and generates high-quality samples for research. By utilising cutting-edge technologies on synovial biopsies with corresponding clinical information, a precision-based medicine approach for patients with RA is attainable.

Disclosure of Interest: None declared

DOI: 10.1136/annrheumdis-2018-eular.7594

\section{AB0228 INCREASE IN GLOBAL DNA METHYLATION AT 3 MONTHS OF METHOTREXATE USE IS NOT ASSOCIATED TO RESPONSE IN EARLY RA PATIENTS}

H.R. Gosselt ${ }^{1}$, M.C. de Rotte ${ }^{1}$, J.M. Hazes ${ }^{2}$, R. de Jonge ${ }^{3}$, S.G. Heil ${ }^{1} .{ }^{1}$ Clinical Chemistry, ${ }^{2}$ Rheumatology, Erasmus Medical Center, Rotterdam; ${ }^{3}$ Clinical Chemistry, VU Medical Center, Amsterdam, Netherlands

Background: Methotrexate (MTX) is a first-line therapy in early Rheumatoid Arthritis (eRA). Still, up to $40 \%$ of treated patients do not adequately respond to MTX. MTX interferes with the folate cycle, where it indirectly inhibits the global DNA methylation donor S-adenosylmethionine (SAM). Thus, we hypothesised that global DNA methylation changes during MTX use are associated with treatment response.

Objectives: To examine whether there is a change in global DNA methylation ( $\Delta \%$ Meth) upon MTX use and if this change is associated to MTX response ( $\triangle$ DAS28) in eRA patients.

Methods: DNA was isolated from whole blood $(n=120)$ and Peripheral Blood Mononuclear Cells (PBMCs, $n=83$ ) of eRA patients, before and 3 months after MTX use. Samples were collected from the Treatment in the Rotterdam Early Arthritis Cohort (tREACH), a multicenter, stratified single-blind clinical trial of eRA patients. Selected patients received triple (MTX $+\mathrm{SSZ}+\mathrm{HCQ}$ ) or monotherapy (MTX) combined with corticosteroids. 7 CpG sites within Long-Interspersed Nuclear Elements (LINE-1), a proxy for global DNA methylation, were quantified by Sequenom Epityper. Paired t-tests or Wilcoxon Signed Rank tests were conducted to assess a change in methylation. $\triangle \mathrm{DAS} 28$ score over 3 months was used as a measure for response. Associations between $\triangle \mathrm{DAS} 28$ and $\Delta \%$ Meth were corrected for baseline DAS28 in a linear regression model. 